\title{
A (Class)Room with a View: How Fiction Can Help New Teachers
}

\author{
SUSAN BARBER \\ Simon Fraser University
}

In teacher education programs there is much vocal support surrounding the idea of using creative materials to encourage innovative ways of seeing and learning. Yet these programs sometimes struggle to teach through arts-based texts that facilitate both wider and deeper knowledge of the self and others. The reason for this may be twofold: first, there may be a lack of understanding or appreciation of narrative inquiry, and second, examples of targeted pedagogical literature are scarce. In this article, I would like to explore the value of teaching through literature and creative writing, and in particular, focus on how stories written by and for new teachers can be significant in shaping positive identities for their new profession.

Instructors in teacher education programs have much to teach and they often welcome creative strategies that open up new ways of seeing and learning. Many years ago in my own Professional Development Program (PDP), I discovered that keeping a journal and writing reflections were valuable ways of grappling with complex pedagogical ideas and experiences. With hindsight, however, I now feel that a related and more effective means towards understanding how one becomes a teacher is not being used to best advantage, and that is through the writing of stories. In writing my own fiction about teachers, I've found it necessary to examine multiple levels of classroom interactions. Specifically, this requires more holistic thinking about who teachers are, what conflicts exist between them and others, and what kinds of relationships they have with students and society at large. By imagining characters in "made up" schools and situations and "seeing" events unfold, I strongly feel that there is a different and more significant kind of knowledge to be gained. It is possible to discover not only what actions lead to certain consequences but also what beliefs and understandings may be held about them.

Fiction, however, is only one type of creative writing that enables students to find out what they think and feel about particular topics. Fiction allows a certain freedom to experiment and ask, "What if...?" but when more broadly cast as narrative, it can include stories and/or descriptions of actual or fictional events, which may appeal to more instructors and students as a means of providing wider and deeper knowledge of the self and others. Here I will talk about "stories" as fiction but the larger sense of narrative also applies.

In this article I would like to discuss how some of these ideas transpired in two PDP courses and how it became clear to me that all students, especially pre-service teachers, could learn a great deal from both reading and writing stories. Lastly, at the end of this article, I have included an excerpt from a novel that might illustrate the type of "pedagogical" literature I'm suggesting might be useful for new teachers.

(C) Copyright 2008. The author, Susan Barber, assigns to the SFU Educational Review the right of first publication and educational and non-profit institutions a non-exclusive license to use this document for personal use and in courses of instruction provided that the article is used in full and this copyright statement is reproduced. Any other usage is probibited without the express permission of the author. 
Bloom (1994) says, "we read to fortify ourselves." Fiction can go a long way toward creatively helping students imagine themselves on the paths toward becoming better people as well as better teachers. Nussbaum (1997, p. 10-11) describes it as developing a

narrative imagination. This means the ability to think what it might be like to be in the shoes of a person different from oneself, to be an intelligent reader of that person's story, and to understand the emotions and wishes and desires that someone so placed might have.

Many of my PDP students were English majors and had read significant amounts of literature. They were familiar with the deep pleasure literature can afford and most expressed the thought that good novels could "change your life." They also voiced opinions echoed by researchers in the field (Steiner 1989, Nussbaum 1990), about what can be learned from reading literature. For one thing, literature takes a person out of his or her daily life and provides an opportunity to experience vicariously situations never before encountered. If the reader agrees to let go of reality and suspend disbelief she can use her imagination to see new worlds through the eyes of characters, who may at first seem incomprehensible. In this way, the reader can travel through time, situate herself in other places, genders, races, cultures, religions and age brackets. According to Nussbaum (1990, p.47),

we can overcome our parochial existence and, through identifying with the 'other', exercise our moral imagination as well. Suddenly we feel we know someone from another group, maybe more intimately than people in our own circle, and we can no longer accept stereotypes or prejudices.

Perhaps for thinking and feeling readers, one of the greatest accomplishments of literature is that it precipitates a more authentic understanding and compassion for fellow human beings.

The collective story my PDP students told me about their histories as creative writers, however, was a sad one. They remembered entering elementary school with a world of imagination in their hearts and minds, and enjoying writing stories. They frequently shared their experiences from home; how their dog ate the birthday cake, or what it felt like the first time they rode a bike. This fits with what literacy experts Cunningham, Moore, Cunningham and Moore (2004) say about "feeling being the energizer for reading and writing" when authors have a personal investment in their stories. The affective component boosts the effort required to get the words down on the page. Children often possess a sense of beginnings, middles and ends, and know how to entertain their audience with the rising action that leads to the climax. This adds up to students taking great pleasure in telling and writing stories and wanting to do more of it. Most importantly, students begin to experience success in communicating ideas and start to see themselves as writers.

Unfortunately, my PDP students' enthusiasm for creative writing seemed to dissipate over the years. Around Grades 5-7, a shift in focus occurred in the teaching of writing where they felt they were asked to work more on technical aspects, such as using correct grammar, spelling and punctuation, and mastering the traditional academic essay. In the higher grades, even among those who said they continued to write creatively, many felt they lost interest and confidence when they compared their efforts to the literature they were reading in class. What seemed most disturbing was that no one could remember having done any creative writing during their undergraduate years.

At the beginning of our semester, I believed engaging with fiction would be a help to these pre-service teachers, mainly for the insights it would afford on teaching literature and writing in their own future classrooms. As the weeks went on, however, the idea evolved into something unexpected.

My plan was to provide a setting where they could take chances again in creative writing, not only to revive artistic self-expression but also to recover the enthusiasm and confidence of their childhood selves as authors. Knowing it had been a long time since most of them had attempted to 
write stories, I eased into our writing assignments with great care. We began with pre-writing activities, oral storytelling, journal and blog entries, quickwrites - all designed to get them back in the "habit" of writing. Thinking they were familiar with writing reflections in PDP, I imagined it would be a short, parallel step into narrative fiction, but I was surprised to hear how some had struggled to get something on the page. It became important to emphasize in class how our creative writing activities would differ from their earlier and perhaps negative experiences. The main idea was to focus on the process. The creative, discovery stage is too often overrun by the technical, editing stage. These are two distinct mental processes where the latter must be kept at bay until the initial ideas clearly take hold. (Mamchur 1995).

Although students were allowed to self-select subjects to write about, several chose to describe teaching experiences. At this point another idea began to form and I realized how worthwhile it might be to ask them to read and write stories specifically about becoming teachers. In class, we tried to brainstorm the names of texts that showed how teachers adapt to their new roles. Strangely enough, although many novels and short stories involve teachers and schooling situations, films more readily came to mind. Some of the most common plots centered on the ways teachers inspire students to finish school and achieve their potential; for example, Stand and Deliver, Finding Forrester, Dead Poets Society, October Sky, Mona Lisa Smile, Lean on Me. Other popular movies named were Freedom Writers, Dangerous Minds, Mr. Holland's Opus, and Music of the Heart. Perhaps less comfortable to consider was Notes on a Scandal.

Clearly all these stories have value but what seems to be missing is a sharp focus on the incremental changes occurring within and around the new teacher. This is both an individual experience and one that follows a general set of steps. These stages have been well documented in educational texts (Bullough 1989; Dollase 1992; Bullough, Knowles and Crow 1992; and Burke 2006). The nature of stories is such that while they deal in particular situations with unique students and teachers, they are also rooted in universal processes. After touching on these ideas in the PDP classes I came to believe that students who are becoming teachers could learn significantly from reading, writing and discussing fiction about the teacher's journey.

Lucy McCormick Calkins (1986, p. 4) writes,

Human beings have a deep need to represent their experience through writing. We need to make our truths beautiful. ... By articulating experience, we reclaim it for ourselves. Writing allows us to turn the chaos into something beautiful, to frame selected moments in our lives, to uncover and celebrate the organizing patterns of our existence. ... We write because we want to understand our lives.

This is especially true for pre-service teachers who are struggling to acquire a large body of new knowledge as well as taking on a substantial amount of professional responsibility. Working out through their writing what they think and feel about their new roles as teachers allows a greater degree of self-awareness, something not as readily available through reading factual accounts. Bullough, Knowles and Crow (1991) say narratives about teaching, compared to the reporting of other types of empirical research, have the unique ability to present the essence of schooling and teaching. Somehow the reality slips through the net of our research paradigms...More wisdom about education is caught in narrative accounts. Furthermore, these authors state (p.1) that,

little is known about the actual process of socialization that takes place from pre-service to the first couple of years of teaching. The central role the beginning teacher plays in her own socialization is understood as a process of learning to participate in a social group, and more broadly speaking, professional development... The teacher enters a teaching context, tries on roles from within a formed self. She then develops a teaching self based on clusters of meanings - tested and adjusted in response to meanings taken from interpretations based on responses of students and others. It is a conflict-laden process and the new teacher needs to make adjustments and compromises where she keeps fine-tuning 
the new self, and "reconstructed" selves are formed. Meanings are layered and form the teaching self. Deeper ones attached to the inner self are often unarticulated.

Although Bullough, Knowles and Crow believe, "Emerging as a teacher is, therefore a quest for compelling and fitting metaphors that represent who beginning teachers imagine themselves to be as teachers," I feel taking the quest beyond metaphor into story writing is an even more worthwhile means of exploring the developing self as teacher. Through reading, writing and sharing stories about situations in educational settings, new teachers can profit from learning about their own views, those of others and even experiences they have not yet encountered.

My response to the above has been to suggest that what is needed is a new genre of literature. Mystery novels, gothic stories, romance literature exist-why not pedagogical literature? This of course would have a very limited range of readers, and some specialized knowledge might be required, but it could appeal in different ways to those who are engaging with educational ideas. Reading stories about teaching professionals, including their personal struggles, can add a more organic or holistic angle to the current body of factual texts. When students read stories about other people, they can't help but bring in their personal experiences, memories and values. They spontaneously imagine how they might act in similar situations.

If students who are becoming teachers can access a variety of stories about how identity is changing as they are in the process of becoming teachers, as well as learning about how they might handle situations they have not yet come across, they might be able to translate some of this knowledge into real life. They would also gradually become aware that their struggles are common to all those who have gone before them into the field. The joys and frustrations these new teachers experience are in fact part of the journey. Literary discussions with peers create support systems and may result in collaborations and group problem solving - skills that will come in handy during their first years of teaching. Most importantly for PDP students is that they are granted a glimpse into the years ahead and can begin to understand what they will experience inside themselves as well as outside. Each new teacher will be in search of a unique identity, bringing special personal traits to an established role in the school, and finding a way to blend the two. Perhaps after reading and imagining how others have done this, new teachers will feel the task is less daunting.

In the next section I would like to share an excerpt from a work in progress that attempts to show a new teacher, Jennifer, actively engaged in finding her way into the profession. To give a bit of context: the story is told from the point of view of her student, Jason, who is looking back on an incident that occurred during Jennifer's first year. Jason is an abused teen who identifies strongly with her efforts to deal with bullies and other difficult students. He notices how she struggles in the classroom, how she must be with the students in order to gain their cooperation. This in turn affects his thinking on how he might apply this knowledge to his own life. In this particular scene Jason is on the brink of understanding that there is a moral stance to be taken in regards to his relationship with his father and that his identity is something he can actively choose.

In the excerpt, Jason has not yet spoken in class and he watches Jennifer scrap one approach for another, which she feels in that particular moment will work better with the students. There are many levels of education at work here that can be pinpointed and used as the basis for discussions; for example, teacher identity, student-teacher relationships, classroom management, contrasting philosophies of education, lesson planning, mentoring and other pedagogical concerns. 


\section{Excerpt from: A Story for My Teacher}

Back at school on Monday, I expected another class of heavy silence and more of Mr. Sennick's student remedies, but this was a new week. You came in class smiling and you cleared your desk of all the textbooks. Then you erased the entire blackboard. One by one the students started watching. When Mrs. Larousse came in to give you a stack of newspapers, your speech was so animated it was like you had been pretending for the last week to be angry or fed up.

At the bell, you clapped your hands together and said, "Okay, class. Please be seated. Today is totally different. It's your turn. Dirk and Thomas? Please. Today I'm not going to be teaching. That's right. You are going to tell me what you think is most important to learn.

"Yah, tell us how to steal cars!"

You grinned and continued, "If you seem to think that poetry or grammar has no use in your life, fine, I'm not going to waste your time. We just need to find a starting point. So, what do you want to learn? What knowledge do you feel you need for living? Take some time right now. I want you to think about it and jot a few ideas down on paper. Do that now."

The room was unusually silent. You walked over to your desk and did the attendance. After a minute you said, "Okay. Anybody? What would you like to learn about?"

"How to grow killer weed?"

A few titters.

You waited. "Serious ideas please. Nobody? This is your big chance." You shrugged. "Okay. Well, for starters, I can tell you the question that has been asked for a couple of thousand years. It might be the oldest and most common question any person thought to ask him or herself. That question is, 'How shall I live my life?' How are you going to choose, yes, you can choose, who you are and what you do. Each person has the power take control of their life. You've probably heard that you don't have to follow the crowd, or do what your parents expect, or accept the limitations around you. You have a choice. Seriously. I'm not talking so much about choosing a job - you can be a mom, be a veterinarian, a truck driver. But the ancient question is asking about how you will be in this world. What kind of person you will be."

You walked briskly to your desk and picked up a pink plastic container. "Tell you what - just to help you do some good thinking today, I've got some homemade cookies here. Each person who contributes something serious to the discussion will get a cookie, maybe two."

"What kind are they?"

“A good kind. So if I ask you, 'how will you live your life?' I'm talking about by which principles. Decide what will guide you. Or, you can turn it around, ask yourself: what qualities do I admire in other people? Maybe something in the way they deal with others. How do they handle things? What kinds of people do you like? Name some personality traits." You rattled the container. "Can you smell them?" You laughed but expected us to talk. A few students shifted in their seats.

Casey sat forward and looked around. "I'm not afraid to say something. I like honest people. No bullshit."

"Okay, honest. In what way honest?"

Casey ran his fingers through his hair. "Well, you know, when they know something you don't know but they don't use it against you. They choose to help you. It's like playing fair cuz they want you to treat them the same way down the road."

"Okay, very good." You held out the cookies and Casey took one. "So, honesty. This could also be called 'being fair' or 'just'. What is justice then? Anyone? Cookies, cookies."

Casey said, "They're good!"

People were looking around the room. Something was happening. I couldn't help looking around. Dirk had a furrow in his brow and Travis and Peter were whispering. Sarah scratched her head. 
You said, "Let me try putting it another way. Why should you be good?"

"Oh, I know," Chris Tomkins said. "Because God wants you to."

There was some laughter but you put up your hand. "No, that's a worthwhile answer. That's what many religions of the world teach. Chris gets a cookie. And let's look at that a little deeper. You can decide to be good for religious reasons but not everyone is religious. Yet most people aren't bad."

Dirk quipped, "You haven't lived in Pike's Mill long enough, Mrs. Brighton."

Only Todd laughed.

"Ms. Brighton. If you look at what religious texts say, it follows a certain kind of reasoning: 'Do unto others as you would have them do unto you.' Or, if you like, more primitively, 'An eye for an eye, a tooth for a tooth."”

Andy jumped in his seat. "Oh, I get it. I'll be good to you and then you'll be good to me, like Casey said. It's an agreement."

"Yes! Let's give that man a cookie! You made a good connection there. But here's the next part: What if... no one is watching? Do you still have to be good? Maybe, or maybe not? Let's say you find an envelope of money on your neighbour's driveway. You're pretty sure it fell out of his or her pocket getting out of the car. They don't know where they lost it, or that you found it. Is it okay to keep it because you won't be caught?

"Keep it!"

"Shut up, jerk."

You said, "Peter, will you please move to the side table? So, you're saying, in the reverse case, if it was you who dropped some money and someone else found it, it would be okay with you if someone else just kept your lost money, even though you now won't have enough money to feed your kids, or heat your house. Tough luck, right?"

"Hey, finders keepers."

"Ah, and that leads to the related question: what if everybody did that? And another question: even if nobody else knew you had taken something that didn't belong to you, how do you think over time you would start to see yourself? Especially if you did this kind of thing all the time? Would you see yourself as an honest person, a good person? You know these kinds of things like keeping lost money harms other people."

"I'd be a smart person!"

"Okay, can you guys in the back turn this way? Dirk, come sit up front. But we're talking about how we are living our lives. All this adds up over time. Why do you think these kinds of acts do no harm to your reputation, nobody thinks any less of you, but you would be doing harm to yourself? Come on, the next cookie is waiting..."

We could hear the murmurs of other classes coming through the door, it was that quiet. Further down the hall the band was practicing in the cafeteria. You waited a little longer then broke the silence. "There are hundreds of thousands, maybe millions of people who earn their money each day, are parents who take care of their kids, lead decent lives, don't think too much about the 'gray areas'. They don't see these things as a big deal. So what? The average person is tempted from time to time to cheat on taxes, or cut out of work early, tell small lies and so on. If they do it, does it cause them any harm?"

"Ms. Brighton, you know the answer. Just tell us!"

"Tell you! That's the whole point. You can think for yourselves."

"Obviously there's a right answer. What is it?"

"Yeah, you're making our heads hurt!"

I raised my hand. The class hushed and turned as one in their seats to look at me. Your words trailed off as you followed their line of attention, and your eyes widened as you saw me. Then you nodded. 
My voice was rough from not speaking. "You should be good, because. Because it is a living thing - inside yourself. You have to take care of it. Anything bad is like a poison that rots your guts."

Everyone listened to the fluorescent lights buzz, and then someone passed by our door and the trance broke.

You exhaled and said, "Thank you, Jason."

My name hung in the air a minute and then Casey said, "You forgot his cookie."

"Yes! of course. Please. And Jason is right. Even if you are surrounded by all kinds of nastiness, you should be good for your own sake. It's so hard, but sometimes you have to stand up and be that one person who says, 'this is not right' or 'I don't agree with this'. Even if no one else appreciates it or acknowledges it. Great. Anyone else?”

I bit into the golden biscuit and the chocolate melted in my mouth. The taste was all I could think of. I couldn't ever remember experiencing anything more true or sweet in my life.

\section{References}

Bloom, Harold. (1994). The Western Canon. New York: Harcourt Brace.

Bullough, Robert V. Jr. (1989). First Year Teacher: A Case Study. NY: Teachers College Press.

Bullough, Robert V. Jr., J. Gary Knowles and Nedra Crow. (1991). Emerging as a Teacher. London: Routledge.

Burke, Jim. (2006). Jim Burke's Letters to a New Teacher: A Month by Month Guide to the Year Ahead. Portsmouth, NH: Heinemann.

McCormick Calkins, L. (1986). Tap the energy to write. The Art of Teaching Writing. Portsmith, New Hampshire: Heinemann.

Cunningham, Patricia M., Sharon Arthur Moore, James W. Cunningham and David W. Moore. (2004). Reading and Writing in Elementary Classrooms: Research Based K-4 Instruction. Boston: Pearson Education, Inc.

Mamchur, Carolyn - I owe many of these ideas to the work of Dr. Mamchur, and her courseware texts for Distance Education at Simon Fraser University (1995):

Educ 485 Designs for Learning: Writing

Educ 412 Designs for Learning: Secondary Language Arts

Nussbaum, Martha (1990). Love's Knowledge. New York: Oxford University Press. -- (1997). Cultivating Humanity: A Classical Defense of Reform in Liberal Education. Cambridge, MA: Harvard University Press.

Steiner, George (1989). Other Voices. Chicago: University of Chicago Press.

\section{About the Author}

Susan Barber is a writer, teacher and PhD student in Arts Education at Simon Fraser University. Her areas of interest are creative writing, aesthetics, philosophy of education, teacher education and literacy. 